\title{
Pengaruh Penguasaan Kompetensi Teknis Terhadap Kinerja Pegawai Yang Dimoderasi Oleh Kompetensi SMART ASN Pada Jabatan Pelaksana Penyusun Bahan Publikasi Dan Kehumasan
}

\author{
${ }^{1}$ Rima Febrina, ${ }^{2}$ Shally Alpriany Aisyah \\ Pusat Pengembangan SDM Aparatur Perhubungan \\ Email:마rimafebrina@gmail.com
}

(Diterima: Juli 2021; Direvisi: Juli 2021; Dipublikasikan: September 2021)

\begin{abstract}
ABSTRAK
Gagasan SMART ASN merupakan langkah menghadapi era revolusi industri 4.0 mengharuskan ASN beradaptasi terhadap transformasi teknologi agar pelayanan publik lebih efektif, efisien, ditunjang dengan kinerja pegawai secara keseluruhan. Hal tersebut berkaitan dengan penguasaan kompetensi teknis yang didukung dengan penguasaan kompetensi penunjang SMART ASN. Jabatan penyusun bahan publikasi dan kehumasan merupakan jabatan yang diperlukan di setiap unit instansi untuk kelancaran informasi. Penelitian ini mengujikan pengaruh penguasaan kompetensi teknis dan kompetensi penunjang SMART ASN serta moderasi SMART ASN terhadap kinerja pegawai penyusun bahan publikasi kehumasan di Kementerian Perhubungan. Hasil analisis menunjukkan penguasaan kompetensi teknis memiliki pengaruh positif terhadap kinerja pegawai, sementara penguasaan kompetensi penunjang SMART ASN berperan sebagai pure moderator yang memperkuat pengaruh penguasaan kompetensi teknis oleh pegawai terhadap kinerjanya. Analisis instrumen menunjukkan bahwa pegawai masih mengalami kesulitan jika ranah kehumasan menjangkau hubungan luar lebih luas seperti media dan redaksi. Pegawai dengan penempatan kantor pusat dan area ibukota provinsi lebih fasih dalam menguasai teknologi sosial media dan kemajuan informasi. Motivasi pegawai untuk melakukan pekerjaan lebih kolaboratif, up to date, dan kreatif masih perlu ditingkatkan.
\end{abstract}

Kata Kunci: SMART ASN, Kompetensi Teknis, Kinerja Pegawai, Kehumasan 


\section{PENDAHULUAN}

Generasi SMART ASN

dibangun sejalan dengan prioritas pembangunan SDM serta grand design reformasi birokrasi nasional. Kebijakan strategis pembangunan SDM Aparatur Sipil Negara (ASN) bertumpu pada reformasi manajemen ASN dalam UU Nomor 5/2014 tentang ASN, PP Nomor 11/2017 tentang Manajemen PNS, dan PP Nomor 49/2018 tentang Manajemen PPPK. SMART ASN adalah harapan di tengah kondisi birokrasi Indonesia yang masih berjalan tidak efektif. Indonesia berada di peringkat ke-77 dari 119 negara dalam Global Talent Competitiveness Index, dengan nilai 38,04 (Menpan.go.id, 2019). Pemerintah mendorong para aparatur mampu beradaptasi menghadapi perubahan eksternal yang bersifat global di lingkungan birokrasi yang terjadi begitu cepat. Dalam hal pengembangan kompetensi dan kesejahteraan ASN, pemerintah memiliki cita-cita menyiapkan SMART ASN di tahun 2024 dengan berbagai kriteria, yaitu harus berintegritas, memiliki rasa nasionalisme tinggi, profesional, berwawasan global, memahami teknologi/informasi dan bahasa asing, hospitality, networking, serta entrepreneurship. Tujuan dari penelitian ini yaitu untuk mengetahui pengaruh kompetensi terhadap kinerja pegawai, pengaruh kompetensi penunjang SMART ASN terhadap kinerja pegawai, dan penguasaan kompetensi teknis dimoderasi oleh penguasaan kompetensi penunjang SMART ASN memberikan pengaruh positif atau negatif terhadap kinerja.
TINJAUAN PUSTAKA

\section{Kompetensi Teknis Manajerial}

$\begin{array}{lrr}\text { Menurut } & \begin{array}{r}\text { Spencer } \\ \text { dikutip }\end{array} \\ \text { Spencer yang } \\ \text { Moeheriono }\end{array}$
competency is an underlying characteristic of an individual that is causally related to criterian referenced effective and or superior performance in a job situation". Dari definisi tersebut dapat diartikan kompetensi merupakan karakteristik yang mendasari seseorang berkaitan dengan efektivitas kinerja individu dalam pekerjaannya atau karakteristik dasar individu yang memiliki hubungan kausal dengan kriteria yang dijadikan acuan, efektif atau berkinerja prima atau superior di tempat kerja atau pada situasi tertentu. Sesuai Peraturan Menteri Pendayagunaan Aparatur Negara dan Reformasi Birokrasi Republik Indonesia Nomor 38 Tahun 2017 tentang Standar Kompetensi Jabatan Aparatur Sipil Negara, kompetensi jabatan yang harus dimiliki oleh setiap Aparatur Sipil Negara (ASN) adalah kompetensi teknis, kompetensi manajerial, dan kompetensi sosial kultural. Kompetensi teknis ini adalah kemampuan kerja setiap Pegawai Negeri Sipil yang mencakup aspek pengetahuan, keterampilan, dan sikap kerja yang mutlak diperlukan dalam melaksanakan tugas-tugas jabatannya.

\section{SMART ASN}

Smart ASN merupakan aparatur yang memiliki profil nasionalisme, integritas, wawasan global, hospitality, networking, teknologi informasi, bahasa asing 
dan entrepreneurship yang berperan sebagai digital talent dan digital leader yang mendukung transformasi birokrasi di Indonesia (Mustafa, 2019:9). Tercapainya SMART ASN 2024 juga sejalan dengan terbentuknya nilai Apartur Sipil Negara 2024, yakni 1) beretika, 2) berpikir strategis, 3) berkolaborasi, 4) berkeputusan tegas, 5) berinovasi, dan 6) bekerja tuntas (Subagja, 2017). Sementara itu, untuk merealisasikan SMART ASN, Kemenpan RB telah memiliki strategi 6P, yakni 1) perencanaan, 2) perekrutan dan seleksi, 3) pengembangan kapasitas, 4) penilaian kinerja dan penghargaan, 5) promosi, rotasi dan karir, dan 6) peningkatan kesejahteraan.

\section{Kinerja Pegawai}

Menurut Gandung, M. dan Suwanto (2020) kinerja adalah hasil kerja secara kualitas yang di capai oleh seorang pegawai dalam melaksanakan tugasnya sesuai dengan tanggung jawab yang diberikan kepadanya. Secara konseptual setiap pegawai dalam suatu unit organisasi atau perusahaan diharapkan untuk memiliki penguasaan terhadap dimensi-dimensi pada framework kinerja. Menurut Koopman, et.al (2011) setidaknya terdapat tiga dimensi dari setiap pegawai untuk mencapai kinerja yang positif, yaitu task performance, contextual performance, dan adaptive performance. Task performance menitikberatkan pada kemampuan pegawai untuk dapat menyelesaikan pekerjaannya, memahami tugas yang dibebankan pada dirinya, memiliki keterampilan dan pengetahuan terhadap jabatannya serta kemampuan pegawai tersebut mengikuti perkembangan ilmu pengetahuan. Sementara itu, contextual performance menilai antusias dari pegawai, motivasi, kreatitivitas, dan dedikasi serta komitmen yang dimiliki pegawai tersebut.

\section{Jabatan Pelaksana Penyusun Bahan Publikasi dan Kehumasan}

Publikasi adalah informasi baik dalam bentuk berita, artikel, karangan khas (human interest) yang telah ditulis atau disiarkan oleh media massa (Wardhani, 2008:9). Sementara itu, Josep A. Devito dalam Darmastuti, 2012:33-34 megatakan bahwa fungsi dari komunikasi massa adalah: 1) Untuk menghibur, 2) Untuk meyakinkan, 3) Untuk mengukuhkan, 4) Untuk mengubah, 5) Untuk menggerakan, 6) Menawarkan etika atau sistem tertentu, 7) Menginformasikan. Pengelolaan komunikasi publik merupakan hal penting dalam sebuah pemerintahan sebagaimana pengelolaan komunikasi publik menjadi sarana penyampaian kebijakan pemerintah, baik program maupun capaian yang disampaikan kepada masyarakat (Ramadani, 2019). Selain itu merujuk Uraian Jenis Kegiatan (UJK) Kementerian Perhubungan PM 147 Tahun 2016 serta KM 84 Tahun 2021 bahwa kebutuhan akan kelompok jabatan pelaksana penyusun bahan publikasi dan kehumasan selalu ada pada setiap unit instansi. 
METODE PENELITIAN

Model Penelitian

Penelitian ini akan menganalisis pengaruh penguasaan kompetensi Aparatur Sipil Negara (ASN) terhadap kinerja. Kompetensi yang dipilih adalah kompetensi manajerial dari kelompok jabatan pelaksana penyusun bahan publikasi dan kehumasan. Penelitian ini juga melihat kompetensi SMART ASN sebagai kompetensi penunjang. Model mengujikan pengaruh langsung penguasaan kompetensi teknis terhadap kinerja, pengaruh langsung penguasaan kompetensi penunjang SMART ASN terhadap kinerja, dan moderasi dari penguasaan kompetensi penunjang SMART ASN terhadap penguasaan kompetensi teknis dan kinerja pegawai. Dibawah ini merupakan diagram model penelitian yang menggambarkan variabel dan hipotesis yang digunakan.

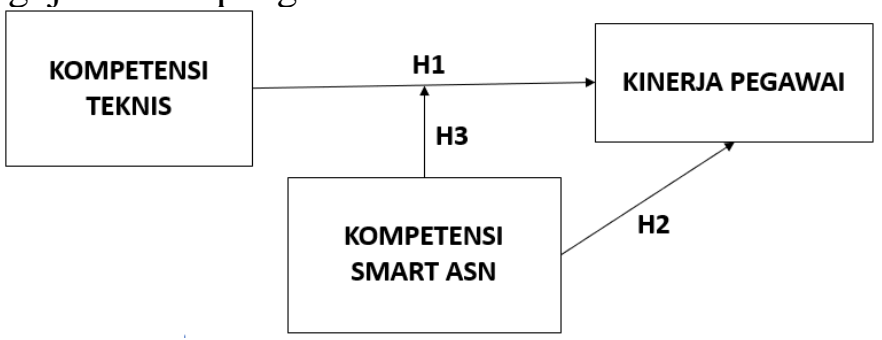

Gambar 1. Model Penelitian

Sumber: Hasil Olahan Peneliti

Variabel penguasaan kompetensi teknis jabatan pelaksana penyusun bahan publikasi dan kehumasan terdiri dari 10 dimensi. Variabel SMART ASN terdiri dari 7 dimensi SMART ASN yang tercantum dalam RPJMN 2020-2024. Kuesioner dibangun dengan metode focus group discussion dengan narasumber Biro Umum Kementerian Perhubungan, studi pustaka, dan merujuk pada Uraian Jenis Kegiatan (UJK) Kementerian Perhubungan PM 147 Tahun 2016, KM 84 Tahun 2021. Penilaian variabel kinerja pegawai terdiri dari 10 (sepuluh) butir pertanyaan merujuk pada Pedro,et.al (2019).

\section{Hipotesis Penelitian}

Hipotesis pada penelitian ini adalah:

H1 : Penguasaan kompetensi teknis memiliki pengaruh yang positif terhadap kinerja pegawai.

$\mathrm{H} 2$ : Penguasaan kompetensi penunjang SMART ASN memiliki pengaruh yang positif terhadap kinerja pegawai.

H3 : Penguasaan kompetensi teknis dimoderasi oleh penguasaan kompetensi penunjang SMART ASN dan memiliki pengaruh positif atau negatif dengan kinerja pegawai.

\section{Sampel Penelitian}

Sampel pada penelitian ini ada pejabat pelaksana (fungsional umum) penyusun bahan publikasi dan kehumasan di Kementerian Perhubungan. Data diambil dari Sistem Informasi Kepegawaian tahun. Rumus Slovin digunakan untuk menentukan jumlah sampel minimum dengan nilai confidence 
level 0.05 untuk tingkat kepercayaan 95\%. Sampel yang diperoleh sebanyak 94 responden yang tersebar di unit-unit kerja Kementerian Perhubungan seluruh Indonesia.

\section{Pengumpulan dan Pengolahan Data}

Pretest dilakukan terhadap 30 sampel diluar responden penelitian dengan mengambil kelompok jabatan pelaksana penyusun bahan publikasi dan kehumasan di lingkungan ASN. Indikator melakukan pengecekan validitas adalah Kaiser-Meyer-Olkin (KMO)-Measures of Sampling Tabel 1. Hasil Uji Validitas Pretest

\begin{tabular}{llllllll}
\hline Variabel & Dimensi & KMO & $\begin{array}{l}\text { Bartlett's } \\
\text { Test }(\text { sig) }\end{array}$ & Variabel & Dimensi & KMO & $\begin{array}{l}\text { Bartlett's } \\
\text { Test (sig) }\end{array}$ \\
\hline \multirow{6}{*}{ KT1 } & 0.709 & 0.000 & IT & 0.690 & 0.000 \\
& KT2 & 0.764 & 0.000 & Bahasa & 0.791 & 0.000 \\
Kompetensi & KT3 & 0.825 & 0.000 & Asing & Hospitality & 0.658 & 0.000 \\
Teknis & KT5 & 0.767 & 0.000 & & Networking & 0.650 & 0.000 \\
& KT6 & 0.790 & 0.000 & & Entrepreneur & 0.653 & 0.000 \\
& KT7 & 0.858 & 0.000 & Kinerja & & 0.727 & 0.000 \\
& KT8 & 0.838 & 0.000 & Pegawai & & & \\
Kompetensi & KT10 & 0.852 & 0.000 & & & & \\
SMART & Integritas & 0.768 & 0.000 & & & & \\
ASN & WawasanLuas & 0.733 & 0.000 & & & & \\
\hline
\end{tabular}

Sumber: Hasil Olahan Peneliti

Dimensi-dimensi yang digunakan untuk setiap variabel dalam model penelitian telah memenuhi nilai validitas dan reliabitas.

Tabel 2. Hasil Uji Reliabilitas Pretest

\begin{tabular}{llllll}
\hline Variabel & Dimensi & $\begin{array}{l}\text { Cronbach's } \\
\text { alpha }\end{array}$ & Variabel & Dimensi & $\begin{array}{l}\text { Cronbach's } \\
\text { alpha }\end{array}$ \\
\hline \multirow{6}{*}{ Kompetensi } & 0.854 & & Integritas & 0.733 \\
& KT2 & 0.822 & & WawasanLuas & 0.863 \\
Teknis & KT3 & 0.853 & Kompetensi & IT & 0.847 \\
& KT5 & 0.846 & SMART & BahasaInggris & 0.903 \\
& KT6 & 0.862 & ASN & Hospitality & 0.805 \\
& KT7 & 0.862 & & Networking & 0.790 \\
& KT8 & 0.900 & & Entrepreneur & 0.712 \\
& KT9 & 0.879 & Kinerja & & 0.723 \\
& KT10 & 0.926 & Pegawai & & \\
\hline
\end{tabular}

Sumber: Hasil Olahan Peneliti

Adequacy (MSA) dengan nilai yang diterima lebih besar dari 0.5 dan signifikansi Bartlett's Test lebih kecil dari 0.05. Reliabilitas diukur dengan Cronbach's Alpha yang dipersyaratkan adalah >0.6. Waktu pelaksanaan pengumpulan data selama 2 (dua) bulan pada bulan Oktober-November 2020.

Dari 30 responden pretest selanjutnya dilakukan perhitungan terhadap nilai-nilai KMO-MSA. Hasil uji validitas dapat dilihat pada tabel berikut: 


\section{HASIL PENELITIAN}

\section{Analisis Responden}

Berdasarkan sebaran survey yang telah dilakukan, berikut adalah analisis data responden:
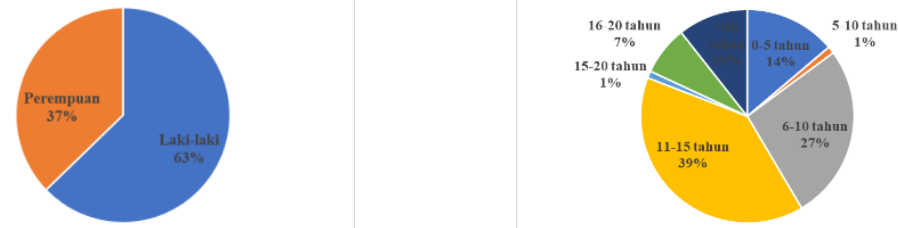

Gambar 2. Persentase Jenis Kelamin dan Masa Kerja Responden Sumber: Hasil Olahan Peneliti

Pelaksana penyusun bahan Kementerian Perhubungan. Distribusi publikasi dan kehumasan Kementerian Perhubungan memiliki masa kerja paling banyak 11-15 tahun sebagai Aparatur Sipil Negara di usia responden didominasi $28 \%$ responden berada pada usia 36-40 tahun, dan $38 \%$ responden di usia $>40$ tahun.
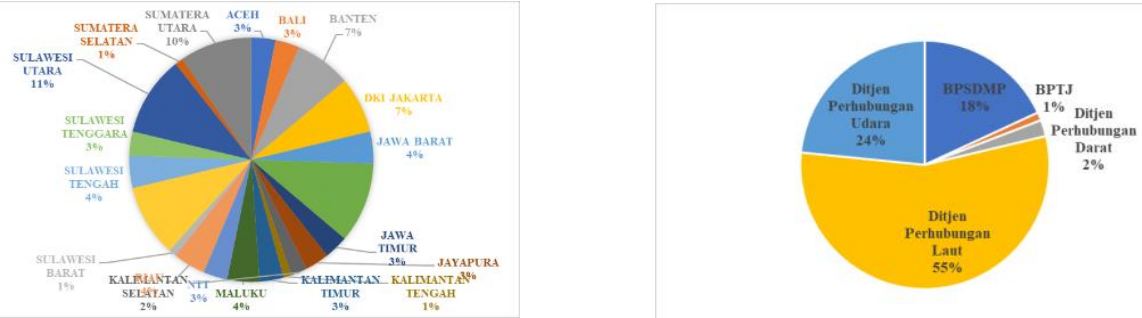

Gambar 3. Persentase Sebaran Provinsi Penempatan Kerja dan Unit Eselon 1

\section{Uji Hipotesis}

Uji hipotesis menggunakan teknik regresi berganda. Terdapat syarat yang harus dipenuhi sebelum uji hipotesis, yaitu uji normalitas dan uji multikolinieritas. Uji normalitas dilakukan dengan tes Kolmogorov-
Smirnov ketika nilai signifikansinya > 0.05. Uji multikolinieritas dianalisis melalui nilai tolerance dan variance inflation factor (VIF) dengan nilai yang masih dapat diterima adalah 10.

Tabel 3. Hasil Uji Normalitas dan Multikolinieritas Penelitian

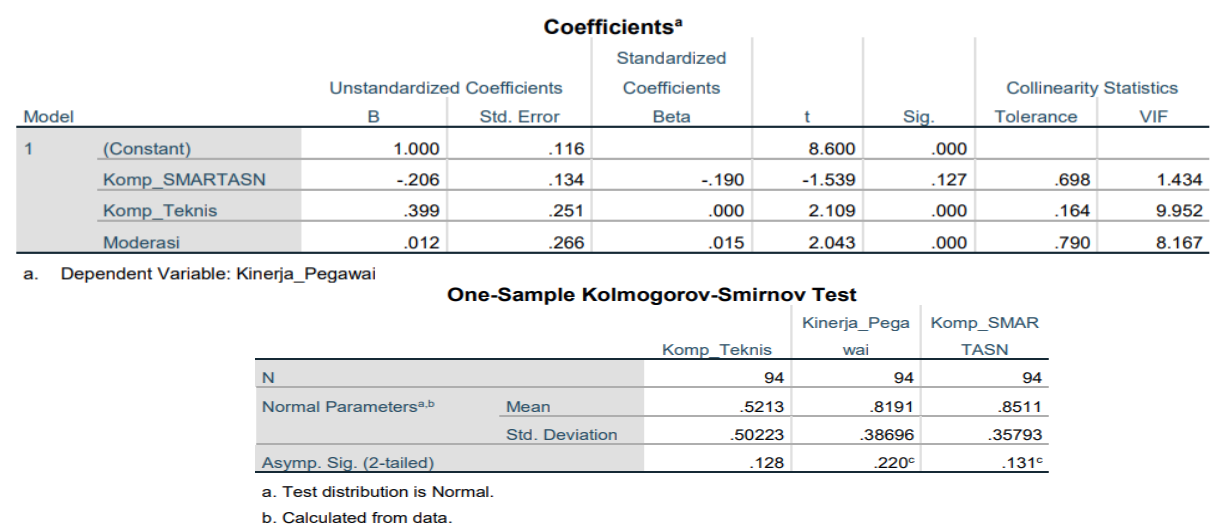

Sumber: Hasil Olahan Peneliti 
Dari hasil olahan data penelitian terlihat bahwa nilai VIF seluruh variabel berada pada nilai dibawah 10 , artinya tidak terjadi multikolinieritas variabel dalam penelitian ini. Nilai normalitas Kolmogorov-Smirnov >0.05 yang menunjukkan bahwa data penelitian telah terdistribusi normal. Uji hipotesis moderasi dilakukan dengan teknik MRA (Moderated Regression Analysis) dimana terdapat unsur interaksi pada regresi linier berganda. Dengan tingkat kepercayaan 95\%, adanya pengaruh dilihat dari nilai signifikansi (sig.) $<0.05$ dan nilai t-hitung > t-tabel $(1,986)$ maka Ha diterima. Pada hasil analisis regresi berganda diperoleh nilai signifikansi $0.000<0.05$ dan nilai t-hitung $2.109<$ t-tabel untuk variabel kompetensi teknis maka pengaruh kompetensi teknis terhadap kinerja pegawai signifikan. Hasil uji-t statistik dari variabel kompetensi penunjang SMART ASN terhadap pengaruh langsungnya dengan kinerja pegawai memiliki nilai siginifikansi $0.127>0.05$ dan $\mathrm{t}$ hitung $-1.539<-1.96$, maka variabel kompetensi SMART ASN tidak berpengaruh signifikan terhadap kinerja pegawai. Dari hasil analisis regresi uji hipotesis diambil hasil penelitian bahwa $\mathrm{H} 1$ yang menyatakan bahwa penguasaan kompetensi teknis memiliki pengaruh yang positif terhadap kinerja pegawai terbukti. $\mathrm{H} 2$ yang menyatakan bahwa adanya pengaruh positif dari penguasaan kompetensi penunjang SMART ASN terhadap kinerja pegawai tidak terbukti. Kemudian, untuk mengujikan hipotesis moderasi pada $\mathrm{H} 3$ memperhatikan signifikansi dari kompetensi penunjang SMART ASN sebagai variabel independen dan interaksi moderasi, Kompetensi Teknis*Kompetensi SMART ASN. Signifikansi kompetensi penunjang SMART ASN untuk pengaruhnya langsung terhadap kinerja pegawai tidak siginifikan, sementara itu interaksi moderasi untuk pengaruh langsung terhadap kinerja pegawai bersifat signifikan. Hasil dari penelitian adalah terjadi moderasi yang dilakukan kompetensi penunjang SMART ASN terhadap hubungan antara kompetensi teknis dan kinerja. Pengaruh moderasi yang dilakukan variabel kompetensi penunjang SMART ASN bersifat memperkuat hubungan antara kompetensi teknis dan kinerja pegawai, maka $\mathrm{H} 3$ terbukti. Variabel moderasi penguasaan kompetensi penunjang SMART ASN dikategorikan sebagai pure moderator yang tidak berfungsi sebagai variabel prediktor.

\section{PEMBAHASAN}

1. Penguasaan Kompetensi Teknis Pejabat Pelaksana Penyusun Bahan Publikasi dan Kehumasan Terhadap Kinerja Pegawai

Pada penelitian ini, fokus kinerja pegawai dari pejabat pelaksana penyusun bahan publikasi dan kehumasan dilihat dengan penilaian terhadap penguasaan kompetensi teknis pegawai berdasarkan Uraian Jenis Kegiatan (UJK) yang terstandarisasi di lingkungan 
Kementerian Perhubungan.

Penilaian penguasaan kompetensi teknis pegawai disusun sedemikian rupa untuk dapat melihat task performance, contextual performance, dan adaptive performance. Berdasarkan uji hipotesis, penguasaan kompetensi teknis pegawai memiliki pengaruh terhadap kinerja yang dapat diartikan bahwa ketika pegawai

Tabel 4. Persentase Penguasaan Kompetensi Teknis Pelaksana Penyusun Bahan Publikasi dan Kehumasan

\begin{tabular}{|c|l|c|c|}
\hline Kode & \multicolumn{1}{|c|}{ Kompetensi Teknis } & $\begin{array}{c}\text { Menguasai } \\
\text { (YA) }\end{array}$ & $\begin{array}{c}\text { Tidak/belum } \\
\text { Menguasai } \\
\text { (TIDAK) }\end{array}$ \\
\hline KT1 & $\begin{array}{l}\text { Kemampuan membuat berita di suatu media di portal/website } \\
\text { Kementerian Perhubungan }\end{array}$ & $73,1 \%$ & $26,9 \%$ \\
\hline KT2 & $\begin{array}{l}\text { Kemampuan membuat bahan liputan media, press tour, dan } \\
\text { kegiatan konferensi internasional transportasi yang } \\
\text { diselenggarakan di Indonesia }\end{array}$ & $53,5 \%$ & $46,5 \%$ \\
\hline KT3 & $\begin{array}{l}\text { Kemampuan membuat bahan press background dan } \\
\text { pertemuan redaktur media }\end{array}$ & $41,5 \%$ & $\mathbf{5 8 , 5 \%}$ \\
\hline KT4 & $\begin{array}{l}\text { Kemampuan membuat siaran pers, pers release, dan bahan } \\
\text { pemberitaan lainnya }\end{array}$ & $47,1 \%$ & $\mathbf{5 2 , 9 \%}$ \\
\hline KT5 & $\begin{array}{l}\text { Kemampuan membuat bahan kegiatan lokakarya untuk } \\
\text { pers/media }\end{array}$ & $43,1 \%$ & $\mathbf{5 6 , 9 \%}$ \\
\hline KT6 & Kemampuan menganalisis opini publik sektor transportasi & $57,7 \%$ & $42,3 \%$ \\
\hline KT7 & Kemampuan melakukan pengelolaan isu sektor transportasi & $47,6 \%$ & $\mathbf{5 2 , 4 \%}$ \\
\hline KT8 & $\begin{array}{l}\text { Kemampuan menganalisis berita sektor transportasi dari } \\
\text { media massa }\end{array}$ & $51,5 \%$ & $48,5 \%$ \\
\hline KT9 & $\begin{array}{l}\text { Kemampuan memahami ragam dan jenis aplikasi media sosial } \\
\text { yang efektif }\end{array}$ & $83 \%$ & $17 \%$ \\
\hline KT10 & $\begin{array}{l}\text { Kemampuan melakukan pengelolaan media sosial yang } \\
\text { efektif }\end{array}$ & $53,3 \%$ & $46,7 \%$ \\
\hline
\end{tabular}

\section{Sumber: Hasil Olahan Peneliti}

Berdasarkan tabel diatas dapat diketahui bahwa masih terdapat penguasaan kompetensi yang menjadi isu bagi para pejabat pelaksana. Banyak dari pelaksana yang masih mengakui kesulitan dalam pembuatan bahan kehumasan jika terkait dengan press background, pers release, dan kegiatan yang terkait dengan hubungan luar yang lebih luas dan redaktur. Dari wawancara yang sudah merasa memiliki kapasitas dan kapabilitas dalam melaksanakan pekerjaan sehariharinya tentu akan diikuti dengan tercapainya tujuan dari pekerjaan itu sendiri maupun tujuan besar dalam lingkup organisasi. Peneliti pun melakukan analisis jawaban responden dari setiap dimensi kompetensi teknis dan dapat dilihat pada tabel dibawah ini: 
Faktor lainnya adalah demografi responden adalah pegawai senior dengan masa kerja diatas 10 tahun. Masa kerja ini belum memetakan berapa lama pegawai tersebut menduduki jabatan sebagai pelaksana penyusun bahan publikasi dan kehumasan. Di Lingkungan Kementerian Perhubungan sendiri ragam nama jabatan pada Sistem Informasi Kepegawaian cukup banyak, sehingga pengelompokkan rumpun jabatan untuk mendapatkan responden agak sulit. Ketika pemetaan dilakukan dan kuesioner dibagikan, ternyata masih ada beberapa responden yang merasa bahwa pengisian pertanyaan terkait kompetensi teknis berbeda dengan kegiatan, tugas, dan pekerjaan yang dilakukan sehari-hari. Sebagian pejabat pelaksana sehari-harinya hanya melakukan fungsi kehumasan dalam konteks pekerjaan yang sederhana, seperti menjadi narahubung dalam acara kantor, seksi dokumentasi, pembuatan laporan kegiatan internal, dan master of ceremony. Dengan demikian, kompetensi kemampuan komunikasi, jurnalistik, dan public relation masih belum tersentuh. Penempatan pejabat pelaksana yang belum sesuai dengan latar belakang, pengalaman, keahlian, dan minat dari pegawai juga dapat membuat rendahnya penguasaan kompetensi teknis yang seharusnya menjadi dasar dan wajib dimiliki oleh pejabat pelaksana. Dari analisis yang dilakukan juga terlihat bahwa banyak responden yang belum mampu menangani isu sektor transportasi. Organisasi memiliki kewajiban untuk memberikan pendidikan dan pelatihan dasar terhadap ilmu transportasi dalam kaitannya pegawai ini bekerja di Kementerian Perhubungan. Motivasi dan kesadaran masih perlu didorong bagi para pegawai secara keseluruhan.

2. Penguasaan Kompetensi Penunjang SMART ASN Pejabat Pelaksana Penyusun Bahan Publikasi dan Kehumasan Terhadap Kinerja Pegawai

Tujuh dimensi dari penguasaan kompetensi SMART ASN dibutuhkan untuk mewujudkan terciptanya ASN berdaya saing dunia. Jika dibandingkan dengan organisasi/ perusahaan privat dan industri kemampuan pegawai dalam hal IT, penguasaan bahasa asing (Bahasa Inggris), networking, jiwa entrepreneurship bukan lagi hal baru. Sedikit berbeda dengan ASN, nuansa persaingan secara digital dan berkelas dunia masih minim. Dari data The Worldwide Governance Indicator yang dirilis Bank Dunia, pada tahun 2019 indeks efektivitas pemerintahan (government effectiveness) Indonesia masih cukup rendah berada pada nilai 0,18 atau peringkat 60 . ASN dituntut untuk lebih kompetitif apalagi dengan adanya pasar tenaga kerja asing yang semakin banyak memasuki Indonesia. Rumpun jabatan publikasi dan kehumasan merupakan salah satu jabatan yang terkait erat dengan kebutuhan penguasaan dimensi-dimensi 
kompetensi pada SMART ASN.

Pegawai pada jabatan ini tidak terlepas dari penggunaan sosial media, penyesuaian tren alat komunikasi dan platform media terkini, penguasaan bahasa dan istilah-istilah asing dalam

Tabel 7. Persentase Penguasaan SMART ASN Pada Pelaksana Penyusun Bahan Publikasi dan Kehumasan

\begin{tabular}{|c|l|c|c|}
\hline Kode & \multicolumn{1}{|c|}{ Kompetensi Penunjang } & $\begin{array}{c}\text { Menguasai } \\
\text { (YA) }\end{array}$ & $\begin{array}{c}\text { Tidak/belum } \\
\text { Menguasai } \\
\text { (TIDAK) }\end{array}$ \\
\hline KP1 & Integritas dalam melaksanakan tugas-tugas jabatan & $87,2 \%$ & $12,8 \%$ \\
\hline KP2 & $\begin{array}{l}\text { Kemampuan wawasan luas baik nasional maupun global } \\
\text { yang menunjang pelaksanaan tugas jabatan }\end{array}$ & $12,5 \%$ & $\mathbf{8 7 , 5 \%}$ \\
\hline KP3 & $\begin{array}{l}\text { Kemampuan memanfaatkan/menggunakan Teknologi } \\
\text { Informasi dan Komunikasi dalam menunjang pelaksanaan } \\
\text { tugas jabatan }\end{array}$ & $80,1 \%$ & $19,9 \%$ \\
\hline KP4 & $\begin{array}{l}\text { Kemampuan penguasaan Bahasa Asing dalam menunjang } \\
\text { pelaksanaan tugas jabatan }\end{array}$ & $59 \%$ & $41 \%$ \\
\hline KP5 & $\begin{array}{l}\text { Kemampuan hospitality dalam menunjang pelaksanaan } \\
\text { tugas jabatan }\end{array}$ & $81,9 \%$ & $18,1 \%$ \\
\hline KP6 & $\begin{array}{l}\text { Kemampuan mempunyai networking yang menunjang } \\
\text { pelaksanaan tugas jabatan }\end{array}$ & $86,2 \%$ & $13,8 \%$ \\
\hline KP7 & $\begin{array}{l}\text { Kemampuan entrepreneurship yang menunjang } \\
\text { pelaksanaan tugas jabatan }\end{array}$ & $87,8 \%$ & $12,2 \%$ \\
\hline
\end{tabular}

Sumber: Hasil Olahan Peneliti

Dari tabel diatas terlihat bahwa isu yang banyak terjadi terkait dengan kemampuan dimensi wawasan luas. Hal ini bersesuaian dengan analisis kompetensi teknis sebelumnya yang menyebutkan bahwa masih banyak pegawai yang belum mampu melakukan pengelolaan terhadap isu. Motivasi pegawai masih agak rendah untuk mau selalu menjadikan dirinya up to date terhadap berita dan informasi yang terjadi. Literasi pegawai pada jabatan pelaksana penyusun bahan publikasi dan kehumasan masih perlu ditingkatkan. Pegawai yang berada didaerah pun cenderung lebih abai dalam kemampuan dirinya untuk membaca, mengkaji, dan mencari pengetahuan baru. komunikasi dan penyampaian berita, kemampuan memperluas dan memperbanyak jaringan, dan lainnya. Persentase penguasaan SMART ASN dapat dilihat pada tabel berikut: 
pegawai juga dimudahkan dengan fitur alih bahasa yang sekarang ini mudah diakses dan digunakan. Kesulitan akan terjadi ketika suatu saat terdapat agenda atau program kerja yang melibatkan pihak asing. Pada akhirnya, penggunaan pihak ketiga sebagai penerjemah masih dilakukan. Rata-rata kemampuan SMART ASN lainnya yang erat irisannya dengan tugas publikasi dan kehumasan, seperti networking, hospitality, entrepreneurship, dan IT sudah dikuasai dengan baik oleh para pegawai.

Penguasaan SMART ASN memperkuat pengaruh dari kompetensi teknis terhadap kinerja pegawai. Hal tersebut dapat menjelaskan mengenai urgensi kompetensi penunjang SMART ASN dalam pekerjaan sehari-hari dari para ASN. Dengan dikuasainya kompetensikompetensi SMART ASN, pegawai dapat melakukan pekerjaan dengan lebih ideal, kolaboratif, up to date, efektif dan efisien. Dengan adanya pandemi Covid 19 saat ini, pegawai dapat melakukan pekerjaan lebih fleksibel secara tempat dan waktu. Tentu hal ini ditunjang dengan kemampuan pegawai untuk beradaptasi dengan teknologi, bahkan dengan melakukan pekerjaan secara virtual, pegawai khususnya pelaksana publikasi dan kehumasan dapat menjangkau area yang lebih luas dan tidak terbatas lokasi geografis melalui platform online meeting dan media sosial.
IMPLEMENTASI MANAJERIAL

Pemetaan pegawai perlu dilakukan dan menjadi bagian yang rutin dilaksanakan oleh kepegawaian organisasi/ unit kerja/ kantor dalam hal kebijakan penempatan pegawai di jabatan tertentu dan persebaran pegawai di daerah-daerah. Unit kerja di daerah umumnya membutuhkan pegawai publikasi dan kehumasan yang berjiwa kompetitif, up to date, baik penguasaan teknologi dan media sosialnya, serta memiliki kreatifitas sehingga dapat menjadi penggerak bagi unit kerja untuk dapat meningkatkan kredibilitas publik, memperkuat hubungan eksternal, dan menggerakkan program kegiatan yang skalanya lebih luas. Perlu dibuat program pelatihan teknis manajerial untuk jabatan pelaksana penyusun bahan publikasi dan kehumasan dan disusun kurikulum pelatihan yang berbasis dimensi dan indikator dari kuesioner yang dibangun. Peningkatan motivasi pegawai dan dorongan literasi dapat dilakukan oleh pimpinan/atasan langsung maupun edukasi dari unit pusat organisasi. Dimasa pembatasan aktivitas sosial seperti saat ini, organisasi dapat membuat Webinar, Bimbingan Teknis dan program pelatihan lainnya yang efisien namun dapat menjangkau lebih banyak peserta guna meningkatkan kapasitas kompetensi teknis maupun kompetensi penunjang SMART ASN.

\section{KESIMPULAN DAN SARAN}

Dari penelitian ini didapatkan kesimpulan bahwa penguasaan kompetensi teknis memiliki pengaruh terhadap kinerja pegawai pada jabatan pelaksana penyusun bahan publikasi dan kehumasan. 
Penguasaan kompetensi penunjang SMART ASN memoderasi secara positif pengaruh dari penguasaan kompetensi teknis terhadap kinerja pegawai. Saran untuk penelitian selanjutnya adalah membangun model dengan variabel prediktor yang lebih kompleks. Selain itu, untuk melihat kompetensi pegawai di suatu jabatan perlu memetakan masa kerja pegawai khusus di jabatan yang dianalisis.

\section{DAFTAR PUSTAKA}

Aditia, D. dan Anggi. (2019). Pengaruh Penerapan SMART ASN terhadap pengelolaan keuangan negara di era Disrupsi Teknologi Indonesia 4.0. Prosiding Seminar Nasional Sains \& Teknologi Informasi (SENSASI), Juli, Halaman 43 51.

Darmastuti, Rini. (2012). Media Relations - Konsep, Strategi, dan Aplikasi. Yogyakarta: Andi Offset.

Gandung, M dan Suwanto. (2020). Analisis Pengaruh Kompensasi Dan Gaya Kepemimpinan Terhadap Kinerja Karyawan Pada PT. Surya Rasa Loka Jaya Di Jakarta Barat. JENIUS. Vol. 3, No. 3, Halaman 236-245.

Kementerian Kesehatan. (2020). Grand Design Pengelolaan ASN Kementerian Kesehatan 2020-2024.

Koopmans,L., Claire, B., Vincent,H., Wilmar,S., Henrica,de Vet., Allard,B. (2011). Conceptual Frameworks of Individual Work Performance. JOEM Vol 53.

Martini,I., Eddy,S., Ketut Elly,S., I Wayan Gde,S. (2020). The dimensions of competency on worker performance mediated by work commitment. Cogent Business \& Management.

Menpan.go.id. (2019). Menciptakan Smart ASN Menuju Birokrasi 4.0. [On line]. Dari: https://www.menpan.go.id/site/ berita-terkini/menciptakansmart-asn-menuju-birokrasi-40 [25 Juni 2021].

Moeheriono. (2010). Pengukuran Kinerja Berbasis Kompetensi. Bogor: Penerbit Ghalia Indonesia.

Mustafa, A.J. (2019). Smart ASN untuk birokrasi Berkelas Dunia 2024. Kementerian Pendayagunaan Aparatur Negara dan Reformasi Birokrasi.

Nurjaya, N., et al. (2021). Pengaruh Kompetensi Sumber Daya Manusia Dan Kemampuan Pemanfaatan Teknologi Terhadap Kinerja Aparatur Desa Pada Kantor Kepala Desa Di Kabupaten Gunungkidul, Yogyakarta. JENIUS (Jurnal Ilmiah Manajemen Sumber Daya Manusia), 4(3), 332-346.

Pedro,J. Ramos,V. Juan, R.B., Elena, F., Linda,K. (2019). Assessing Job Performance Using Brief Self-report Scales: The Case of the Individual Work Performance Questionnaire. Journal of Work and Organizational Psychology.

Pikiran-rakyat. (2019). 37 Persen ASN Miliki Gap Kompetensi. [On line]. Dari: https://www.pikiranrakyat.com/ekonomi/pr01323213/37-persen-asn- 
miliki-gap-kompetensi [25 Juni 2021].

Ruslan, Rosady. (1997). Manajemen

Public Relations dan Media

Komunikasi, Konsepsi, dan Aplikasi. Jakarta: Raja Grapindo Persada.

Salman,M., Showkat,A.G., Imran,S. (2020).

Employee
Competencies as Predictors of Oganizational Performances: A Study of Public and Private Sector Banks. Management and Labour Studies, Halaman: 1-17. Wardhani, Diah. (2008). Media Relations: Sarana Membangun Reputasi Organisasi.

Yogyakarta: Graha Ilmu. 